\title{
Short communication: Viability of culture organisms in honey-enriched acidophilus-bifidus-thermophilus (ABT)-type fermented camel milk
}

\author{
L. Varga, ${ }^{* 1}$ J. Süle, ${ }^{*}$ and P. Nagy† \\ *Faculty of Agricultural and Food Sciences, Institute of Food Science, University of West Hungary, 9200 Mosonmagyaróvár, Hungary \\ †Farm and Veterinary Section, Emirates Industries for Camel Milk and Products, PO Box 294236, Dubai, United Arab Emirates
}

\begin{abstract}
The aim of this research was to monitor the survival during refrigerated storage of Lactobacillus acidophilus LA-5 (A), Bifidobacterium animalis ssp. lactis BB-12 (B), and Streptococcus thermophilus CHCC 742/2130 (T) in cultured dairy foods made from camel and, for comparison, cow milks supplemented with black locust (Robinia pseudoacacia L.) honey and fermented by an acidophilus-bifidus-thermophilus (ABT)-type culture. Two liters of dromedary camel milk and $2 \mathrm{~L}$ of cow milk were heated to $90^{\circ} \mathrm{C}$ and held for $10 \mathrm{~min}$, then cooled to $40^{\circ} \mathrm{C}$. One half of both types of milk was fortified with black locust honey at the rate of $5.0 \%$ (wt/vol), whereas the other half was devoid of honey and served as a control. The camel and cow milks with and without honey were subsequently inoculated with ABT-5 culture and were fermented at $37^{\circ} \mathrm{C}$ until a $\mathrm{pH}$ value of 4.6 was reached. Thereafter, the probiotic fermented milks were cooled to $15^{\circ} \mathrm{C}$ in ice water and were each separated into 18 fractions that were transferred in sterile, tightly capped centrifuge tubes. After $24 \mathrm{~h}$ of cooling at $8^{\circ} \mathrm{C}(\mathrm{d} 0)$, the samples were stored at refrigeration temperature $\left(4^{\circ} \mathrm{C}\right)$. Three tubes of all 4 products (i.e., fermented camel and cow milks with and without honey) were taken at each sampling time (i.e., following $0,7,14,21,28$, and $35 \mathrm{~d}$ of storage), and the counts of characteristic microorganisms and those of certain spoilage microbes (yeasts, molds, coliforms, Escherichia coli) were enumerated. The entire experimental program was repeated twice. The results showed that addition of black locust honey at $5 \%$ to heat-treated camel and cow milks did not influence the growth and survival of starter streptococci during production and subsequent refrigerated storage of fermented ABT milks. In contrast, honey improved retention of viability of $B$. animalis ssp. lactis $\mathrm{BB}-12$ in the camel milk-based product during storage at $4^{\circ} \mathrm{C}$ up to 5 wk. No spoilage organisms were detected in any of the
\end{abstract}

Received April 28, 2014.

Accepted July 19, 2014.

${ }^{1}$ Corresponding author: VargaL@mtk.nyme.hu samples tested in this study. In conclusion, supplementation of cultured dairy foods, especially those made from camel milk, with honey is recommended because honey is a healthy natural sweetener with a variety of beneficial microbiological, nutritional, and sensory properties.

Key words: Bifidobacterium, camel, fermented milk, honey

\section{Short Communication}

Milking animals are not limited to cows in several parts of the world. Camel milk is available in significant quantities in the arid zones of Africa and Asia (El-Salam, 2011). Consumer interest in camel milk is increasing in many countries, as this product is known to be beneficial for infants allergic to bovine milk because it lacks $\beta$-LG, being similar to human milk in this respect (Fukuda, 2013). The mean values of camel milk composition reported from 1905 through 2009 are $87.53 \%$ moisture, $4.46 \%$ lactose, $3.82 \%$ fat matter, $3.35 \%$ total protein, and $0.79 \%$ minerals (Konuspayeva et al., 2009). $\beta$-Casein is the dominant casein in camel milk (El-Agamy, 2009), and the major whey proteins include $\alpha$-LA and serum albumin (Laleye et al., 2008). Compared with cow milk and milk of small ruminants, camel milk contains reduced amounts of short-chain $\left(\mathrm{C}_{4}-\mathrm{C}_{12}\right) \mathrm{FA}$ and increased levels of medium- and longchain $\left(\mathrm{C}_{14}-\mathrm{C}_{18}\right) \mathrm{FA}$ (El-Agamy, 2006, 2009). It is higher in sodium and calcium than milks of other species (Fukuda, 2013). Furthermore, camel milk is a good source of certain vitamins. For instance, its vitamin $\mathrm{C}$ content can be as much as 10 times higher than that of bovine milk (Konuspayeva et al., 2010). The aforementioned compositional differences between camel and cow milks may influence the growth and viability of lactic acid bacteria and bifidobacteria strains commonly employed in fermented dairy foods (Varga et al., 2014).

Because of its healthy qualities, honey is increasingly used as a natural sweetener in various food products, including cultured milks (Varga, 2006; Süle and Varga, 2009; Sert et al., 2011). Honey-fortified foods are viewed as value-added products, and consumers are willing to pay a premium for them (Ustunol and Gandhi, 2001). 
The presence of honey in fermented bovine milks may increase the viability retention of culture organisms, most notably that of Bifidobacterium spp. (Ustunol and Gandhi, 2001; Süle and Varga, 2009).

The primary purpose of the current research was to monitor the survival during refrigerated storage of Lactobacillus acidophilus LA-5 (A), Bifidobacterium animalis ssp. lactis BB-12 (B), and Streptococcus thermophilus CHCC 742/2130 (T) in cultured dairy foods made from camel and, for comparison, cow milks supplemented with honey at the rate of $5 \%$ and fermented by an acidophilus-bifidus-thermophilus (ABT)-type culture. Black locust (Robinia pseudoacacia L.) honey was used for the trials because of its high commercial value and its abundant supply in Hungary (Varga, 2006). To our knowledge, ours is the first scientific study evaluating the growth and viability of bifidobacteria and lactic acid bacteria in honey-enriched fermented camel milk.

Dromedary camel milk containing (per kilogram) 897 $\mathrm{g}$ of moisture, $23.1 \mathrm{~g}$ of fat, $28.5 \mathrm{~g}$ of protein, $43.8 \mathrm{~g}$ of lactose, and $7.6 \mathrm{~g}$ of ash was supplied by Emirates Industries for Camel Milk and Products (Dubai, United Arab Emirates). It was transported by air from the United Arab Emirates to Hungary under refrigeration at $4^{\circ} \mathrm{C}$ and was processed within $48 \mathrm{~h}$ from the time of milking. The chemical composition of bovine milk, obtained from Lajta Hanság Inc. (Mosonmagyaróvár, Hungary), was $877.9 \mathrm{~g} / \mathrm{kg}$ of moisture, $37.1 \mathrm{~g} / \mathrm{kg}$ of fat, $32.5 \mathrm{~g} / \mathrm{kg}$ of protein, $45.7 \mathrm{~g} / \mathrm{kg}$ of lactose, and $6.8 \mathrm{~g} / \mathrm{kg}$ of ash. Before processing, both types of raw milk were tested for aerobic mesophilic microorganisms (ISO, 2013), yeasts and molds (ISO, 2008), and Enterobacteriaceae (ISO, 2004). The aerobic mesophilic counts in camel and cow milks were $7.3 \times 10^{3}$ and $4.8 \times$ $10^{3} \mathrm{cfu} / \mathrm{mL}$, respectively, and all of the samples tested contained less than $10 \mathrm{cfu} / \mathrm{mL}$ of yeasts, molds, and enterobacteria.

Black locust honey was purchased from a small-scale honey producer in Kisbodak, Hungary. The general microbiological quality of honey was found to be high. Its total plate count was below $10 \mathrm{cfu} / \mathrm{g}$. Similarly, no sulfite-reducing clostridia, molds, or yeasts were detected $(<10 \mathrm{cfu} / \mathrm{g})$ in the sample of black locust honey used for this trial, and Salmonella spp. were also absent in $25 \mathrm{~g}$ of sample.

The ABT-5 culture, which consisted of L. acidophilus LA-5, B. animalis ssp. lactis BB-12, and Strep. thermophilus CHCC 742/2130, was received from Chr. Hansen (Hørsholm, Denmark) in lyophilized direct vat set (DVS) form. Freeze-dried DVS cultures are guaranteed to contain at least $5.0 \times 10^{10} \mathrm{cfu} / \mathrm{g}$ of viable cells (Chr. Hansen A/S, 2001).

Two liters of camel milk and $2 \mathrm{~L}$ of cow milk were heated to $90^{\circ} \mathrm{C}$ and held for 10 min in a Pearl M water bath (Julabo Labortechnik, Seelbach, Germany), then cooled to $40^{\circ} \mathrm{C}$. One half (i.e., $1 \mathrm{~L}$ ) of both types of milk were fortified with black locust honey at a concentration of $5.0 \%$ (wt/vol), whereas the other half was devoid of honey and served as a control. The camel and cow milks with and without honey were subsequently inoculated with ABT-5 DVS culture at the rate of 0.2 $\mathrm{g} / \mathrm{L}$, corresponding to $2.0 \%$ ( $\mathrm{vol} / \mathrm{vol}$ ) conventional bulk culture. Milks were fermented at $37^{\circ} \mathrm{C}$ until a $\mathrm{pH}$ value of 4.6 was reached. Thereafter, the fermented ABT milks were cooled to $15^{\circ} \mathrm{C}$ in ice water and were each separated into 18 fractions that were transferred in sterile, tightly capped centrifuge tubes $(50 \mathrm{~mL}$; Greiner Bio One Hungary Inc., Mosonmagyaróvár, Hungary). Thus, a total of 72 units of product were manufactured. After $24 \mathrm{~h}$ of cooling at $8^{\circ} \mathrm{C}(\mathrm{d} 0)$, the samples were stored at refrigeration temperature $\left(4^{\circ} \mathrm{C}\right)$. The entire experimental program was repeated twice.

Three tubes of all 4 products were taken at each sampling time (i.e., after $0,7,14,21,28$, and $35 \mathrm{~d}$ of storage). Samples were aseptically removed from centrifuge tubes and diluted by mixing $10 \mathrm{~mL}$ with $90 \mathrm{~mL}$ of peptone saline water containing $0.1 \%$ casein peptone and $0.85 \%$ sodium chloride. Further dilutions were made as required. Microbiological analyses (i.e., enumeration of ABT culture organisms, yeasts, molds, coliforms, and Escherichia coli) were carried out as described by Varga et al. (2014). The $\mathrm{pH}$ value of samples was determined at room temperature with a Jenway $3510 \mathrm{pH}$-meter and combined glass electrode (Keison Products, Chelmsford, UK) standardized with $\mathrm{pH} 4.00$ and 7.00 standard buffer solutions (Merck KGaA, Darmstadt, Germany).

The results were subjected to ANOVA using the general linear model procedure of Statistica data analysis software system (version 9.0; StatSoft Inc., Tulsa, OK), with product and time as fixed factors and repetition as covariate in the model. Significant differences among the logarithm (base 10) colony-forming units per milliliter or $\mathrm{pH}$ means were determined by using Duncan's multiple comparison test at $P<0.05$ (StatSoft Inc.).

It is clearly evident in Table 1 that addition of black locust honey at $5 \%$ to heat-treated camel and cow milks did not influence $(P>0.05)$ the growth and survival of Strep. thermophilus CHCC 742/2130 during production and subsequent refrigerated storage of fermented ABT milks. This observation is in contrast to the findings of Molan (1992), who showed honey to be inhibitory to various streptococci, although the levels of honey used in his study were not specified. In agreement with previous reports by Varga (2006) and Süle and Varga (2009), Strep. thermophilus was the most numerous culture component in all 4 products both at the start and at the end of the 5-wk storage period. In Hungary, cultured milks are required to contain viable starter 
Table 1. Survival of Streptococcus thermophilus CHCC $742 / 2130$ in control and honey-enriched fermented acidophilus-bifidus-thermophilus (ABT) milks during refrigerated storage at $4^{\circ} \mathrm{C}$

\begin{tabular}{|c|c|c|c|c|c|c|c|c|}
\hline \multirow{2}{*}{$\begin{array}{l}\text { Storage } \\
\text { time (d) }\end{array}$} & \multicolumn{4}{|c|}{ Camel milk } & \multicolumn{4}{|c|}{ Cow milk } \\
\hline & \multicolumn{2}{|c|}{ Control } & \multicolumn{2}{|c|}{ Honey-enriched } & \multicolumn{2}{|c|}{ Control } & \multicolumn{2}{|c|}{ Honey-enriched } \\
\hline 0 & $9.03 \pm 0.06^{\mathrm{a}}$ & 100 & $9.01 \pm 0.06^{\mathrm{a}}$ & 100 & $8.94 \pm 0.12^{\mathrm{a}}$ & 100 & $8.97 \pm 0.12^{\mathrm{a}}$ & 100 \\
\hline 7 & $8.88 \pm 0.06^{\mathrm{a}}$ & 70.0 & $8.86 \pm 0.07^{\mathrm{a}}$ & 74.0 & $8.80 \pm 0.03^{\mathrm{a}}$ & 69.2 & $8.86 \pm 0.20^{\mathrm{a}}$ & 78.4 \\
\hline 28 & $8.98 \pm 0.03^{\mathrm{a}}$ & 87.3 & $8.99 \pm 0.10^{\mathrm{ab}}$ & 99.0 & $8.89 \pm 0.03^{\mathrm{b}}$ & 84.6 & $8.92 \pm 0.03^{\mathrm{ab}}$ & 85.6 \\
\hline 35 & $8.87 \pm 0.14^{\mathrm{a}}$ & 70.0 & $9.04 \pm 0.10^{\mathrm{a}}$ & 110.0 & $8.92 \pm 0.19^{\mathrm{a}}$ & 98.9 & $8.93 \pm 0.03^{\mathrm{a}}$ & 87.6 \\
\hline
\end{tabular}

lactic acid bacteria at levels of at least $10^{7} \mathrm{cfu} / \mathrm{g}$ at the time of consumption (Codex Alimentarius Hungaricus Commission, 2004). Ranging between 8.80 and 9.04 $\log _{10} \mathrm{cfu} / \mathrm{mL}$, Strep. thermophilus counts alone greatly exceeded this value throughout the 5 -wk storage period (Table 1). The viability of Strep. thermophilus is generally reported to be high $\left(>8 \log _{10} \mathrm{cfu} / \mathrm{mL}\right)$ in fermented dairy foods stored refrigerated for up to $6 \mathrm{wk}$ (Antunes et al., 2005; Varga, 2006; Varga et al., 2014). It is worth noting that the viable counts of Strep. thermophilus showed no decline in our honey-fortified fermented camel milk following $35 \mathrm{~d}$ of refrigerated storage (Table 1).

The initial viable cell numbers of $L$. acidophilus LA-5 were considerably lower than those of starter streptococci (Table 2). The cow milk devoid of honey provided better $(P<0.05)$ conditions for the growth of $L$. acidophilus than did the control camel milk. However, honey addition at 5\% improved the growth of L. acidophilus in ABT-type fermented camel milk.
We observed no marked difference in L. acidophilus counts recorded on d 35 among the 4 products tested. Approximately one-fourth to one-half of $L$. acidophilus cells were capable of surviving 5 -wk storage at $4^{\circ} \mathrm{C}$. Our results are in accordance with those of Macedo et al. (2008), who reported a decline of 0.31 and 0.44 $\log _{10}$ cycles in L. acidophilus LA-5 counts in control and honey-fortified fermented milks, respectively, stored at $7^{\circ} \mathrm{C}$ for $35 \mathrm{~d}$.

As shown in Table 3, the initial viable cell counts of B. animalis ssp. lactis BB- 12 were approximately 20 to 30 times higher in the samples tested than the minimum therapeutic threshold of $6 \log _{10} \mathrm{cfu} / \mathrm{mL}$ (Codex Alimentarius Hungaricus Commission, 2004; Kechagia et al., 2013). All 4 cultured dairy foods had comparable ( $P$ $>0.05$ ) bifidobacteria counts on $d 0$, regardless of the type of milk used and the presence or absence of honey in the product. Only moderate changes, not exceeding $0.4 \log _{10}$ cycle, occurred in viability of bifidobacteria during the 35-d storage period. This finding is in agree-

Table 2. Survival of Lactobacillus acidophilus LA-5 in control and honey-enriched fermented acidophilus-bifidus-thermophilus (ABT) milks during refrigerated storage at $4^{\circ} \mathrm{C}$

\begin{tabular}{|c|c|c|c|c|c|c|c|c|}
\hline \multirow{2}{*}{$\begin{array}{l}\text { Storage } \\
\text { time (d) }\end{array}$} & \multicolumn{4}{|c|}{ Camel milk } & \multicolumn{4}{|c|}{ Cow milk } \\
\hline & \multicolumn{2}{|c|}{ Control } & \multicolumn{2}{|c|}{ Honey-enriched } & \multicolumn{2}{|c|}{ Control } & \multicolumn{2}{|c|}{ Honey-enriched } \\
\hline 0 & $7.11 \pm 0.13^{\mathrm{c}}$ & 100 & $7.58 \pm 0.11^{\mathrm{a}}$ & 100 & $7.59 \pm 0.30^{\mathrm{ab}}$ & 100 & $7.29 \pm 0.09^{\mathrm{bc}}$ & 100 \\
\hline 7 & $7.03 \pm 0.20^{\mathrm{ab}}$ & 88.5 & $7.25 \pm 0.02^{\mathrm{a}}$ & 46.2 & $7.21 \pm 0.04^{\mathrm{ab}}$ & 34.8 & $7.19 \pm 0.01^{\mathrm{b}}$ & 80.0 \\
\hline 28 & $6.96 \pm 0.04^{\mathrm{b}}$ & 70.8 & $7.18 \pm 0.09^{\mathrm{a}}$ & 38.5 & $7.31 \pm 0.12^{\mathrm{a}}$ & 45.7 & $7.29 \pm 0.34^{\mathrm{ab}}$ & 100.0 \\
\hline 35 & $6.86 \pm 0.06^{\mathrm{b}}$ & 56.2 & $7.01 \pm 0.13^{\mathrm{ab}}$ & 28.2 & $7.03 \pm 0.02^{\mathrm{a}}$ & 23.9 & $6.97 \pm 0.16^{\mathrm{ab}}$ & 48.5 \\
\hline
\end{tabular}

${ }^{\mathrm{a}-\mathrm{c}}$ Means within a row with different superscripts differ $(P<0.05)$.

${ }^{1}$ Values are means $\pm \mathrm{SD}$ based on 6 observations (3 samples $\times 2$ replicates).

${ }^{2}$ Percent viability $=(\mathrm{cfu} / \mathrm{mL}$ following $n \mathrm{~d}$ of storage $/ \mathrm{cfu}$ per milliliter on $\mathrm{d} 0) \times 100$. 
Table 3. Survival of Bifidobacterium animalis ssp. lactis BB-12 in control and honey-enriched fermented acidophilus-bifidus-thermophilus (ABT) milks during refrigerated storage at $4^{\circ} \mathrm{C}$

\begin{tabular}{|c|c|c|c|c|c|c|c|c|}
\hline $\begin{array}{l}\text { Storage } \\
\text { time (d) }\end{array}$ & \multicolumn{4}{|c|}{ Camel milk } & \multicolumn{4}{|c|}{ Cow milk } \\
\hline 0 & $7.38 \pm 0.04^{\mathrm{a}}$ & 100 & $7.36 \pm 0.05^{\mathrm{a}}$ & 100 & $7.41 \pm 0.21^{\mathrm{a}}$ & 100 & $7.49 \pm 0.23^{\mathrm{a}}$ & 100 \\
\hline 7 & $7.27 \pm 0.23^{\mathrm{ab}}$ & 83.3 & $7.49 \pm 0.20^{\mathrm{a}}$ & 143.5 & $7.13 \pm 0.12^{\mathrm{b}}$ & 50.0 & $7.41 \pm 0.11^{\mathrm{a}}$ & 76.5 \\
\hline 14 & $7.26 \pm 0.05^{\mathrm{b}}$ & 75.0 & $7.56 \pm 0.02^{\mathrm{a}}$ & 156.5 & $7.18 \pm 0.05^{\mathrm{b}}$ & 53.6 & $7.53 \pm 0.04^{\mathrm{a}}$ & 102.1 \\
\hline 35 & $7.05 \pm 0.05^{\mathrm{c}}$ & 45.8 & $7.38 \pm 0.05^{\mathrm{b}}$ & 104.3 & $7.29 \pm 0.42^{\mathrm{abc}}$ & 96.4 & $7.63 \pm 0.06^{\mathrm{a}}$ & 126.5 \\
\hline
\end{tabular}

${ }^{\mathrm{a}-\mathrm{c}}$ Means within a row with different superscripts differ $(P<0.05)$.

${ }^{1}$ Values are means $\pm \mathrm{SD}$ based on 6 observations (3 samples $\times 2$ replicates).

${ }^{2}$ Percent viability $=(\mathrm{cfu} / \mathrm{mL}$ following $n \mathrm{~d}$ of storage $/$ cfu per milliliter on $\mathrm{d} 0) \times 100$

ment with earlier reports that the loss in viability of bifidobacteria up to $6 \mathrm{wk}$ of storage is mostly less than $1 \log _{10}$ cycle (Abu-Taraboush et al., 1998; Gueimonde et al., 2004; Varga et al., 2014). Honey addition at a level of $5 \%$ resulted in an increase $(P<0.05)$ in survival rates of $B$. animalis ssp. lactis in both products (Table 3 ). The bifidobacteria counts observed between d 14 and 35 were higher than those recorded on $\mathrm{d} 0$ in both honey-enriched fermented ABT milks. These results are consistent with previous observations that honey levels at or above $5 \%$ beneficially influence $(P<0.05)$ survival of bifidobacteria in fermented bovine milks stored under refrigeration for $28 \mathrm{~d}$ (Ustunol and Gandhi, 2001; Süle and Varga, 2009; Riazi and Ziar, 2012). Besides glucose and fructose, honey contains various oligosaccharides with a low degree of polymerization, which were hypothesized by Ustunol and Gandhi (2001) to be the favored substrates for bifidobacterial support. Oligosaccharides are known to make up ca. 4 to $11 \%$ of honey composition, depending on the floral source of honey (Shin and Ustunol, 2005).

Both cultured milks and honey are characterized by high acidity, low levels of oxygen, and the presence of several antimicrobial substances. For this reason, certain spoilage or pathogenic microbes cannot grow and survive in such products (Northolt, 1983; Mundo et al., 2004). All 4 probiotic fermented milks proved to be microbiologically safe for consumption because none of the samples tested contained coliforms, molds, or yeasts, indicating the high degree of sanitation during processing and packaging of products.

Ranging between 4.26 and 4.36 , the initial $\mathrm{pH}$ values of fermented ABT milks were only slightly different $(P$ $>0.05)$, and a decline in $\mathrm{pH}$ of not more than 0.1 unit was observed in both honey-containing and control products by the end of the 35-d storage period (data not shown). These results are consistent with those of Süle and Varga (2009), who reported a pH decline of approximately 0.1 units for ABT-type fermented cow milks during 28 wk of storage at $4^{\circ} \mathrm{C}$.

In conclusion, our results showed that the presence of black locust honey at $5.0 \%$ (wt/vol) improved retention of viability of $B$. animalis ssp. lactis BB-12 in an ABTtype fermented camel milk during refrigerated storage up to 5 wk. Fortification of cultured dairy foods, especially those made from camel milk, with honey is suggested because honey is a healthy natural sweetener with a variety of beneficial microbiological, nutritional, and sensory properties.

\section{REFERENCES}

Abu-Taraboush, H. M., M. M. Al-Dagal, and M. A. Al-Royli. 1998. Growth, viability, and proteolytic activity of bifidobacteria in whole camel milk. J. Dairy Sci. 81:354-361. http://dx.doi. org/10.3168/jds.S0022-0302(98)75584-5.

Antunes, A. E. C., T. F. Cazetto, and H. M. A. Bolini. 2005. Viability of probiotic micro-organisms during storage, postacidification and sensory analysis of fat-free yogurts with added whey protein concentrate. Int. J. Dairy Technol. 58:169-173. http://dx.doi. org/10.1111/j.1471-0307.2005.00203.x.

Chr. Hansen A/S. 2001. Product Range: Dairy Cultures. Chr. Hansen A/S, Hørsholm, Denmark.

Codex Alimentarius Hungaricus Commission. 2004. Savanyú tejtermékek (Cultured dairy products). Pages 21-24 in Codex Alimentarius Hungaricus. Tej és Tejtermékek (Dairy Products). Directive 2-51. Codex Alimentarius Hungaricus Commission, Budapest, Hungary.

El-Agamy, E. I. 2006. Camel milk. Pages 297-344 in Handbook of Milk of Non-Bovine Mammals. Y. W. Park and G. F. W. Haenlein, ed. Blackwell Publishing, Ames, IA. 10.1002/9780470999738.ch12.

El-Agamy, E. I. 2009. Bioactive components in camel milk. Pages 159194 in Bioactive Components in Milk and Dairy Products. Y. W. Park, ed. Wiley-Blackwell, Ames, IA. 10.1002/9780813821504.ch6.

El-Salam, M. H. A. 2011. Middle Eastern fermented milks. Pages 503-506 in Encyclopedia of Dairy Sciences. 2nd ed. Vol. 2. J. W. Fuquay, P. F. Fox, and P. L. H. McSweeney, ed. Academic Press, London. UK. 10.1016/B978-0-12-374407-4.00185-0.

Fukuda, K. 2013. Camel milk. Pages 578-593 in Milk and Dairy Products in Human Nutrition: Production, Composition and Health. Y. W. Park and G. F. W. Haenlein, ed. John Wiley \& Sons, Oxford, UK. 10.1002/9781118534168.ch26.

Gueimonde, M., S. Delgado, B. Mayo, P. Ruas-Madiedo, A. Margolles, and C. G. de los Reyes-Gavilán. 2004. Viability and diversity of 
probiotic Lactobacillus and Bifidobacterium populations included in commercial fermented milks. Food Res. Int. 37:839-850. http://dx.doi.org/10.1016/j.foodres.2004.04.006.

ISO (International Organization for Standardization). 2004. Microbiology of food and animal feeding stuffs - Horizontal methods for the detection and enumeration of Enterobacteriaceae-Part 2: Colony count method. International Standard ISO 21528-2:2004. ISO, Geneva, Switzerland.

ISO (International Organization for Standardization). 2008. Microbiology of food and animal feeding stuffs-Horizontal method for the enumeration of yeasts and moulds - Part 1: Colony count technique in products with water activity greater than 0.95 . International Standard ISO 21527-1:2008. ISO, Geneva, Switzerland.

ISO (International Organization for Standardization). 2013. Microbiology of the food chain-Horizontal method for the enumeration of microorganisms - Part 1: Colony count at $30^{\circ} \mathrm{C}$ by the pour plate technique. International Standard ISO 4833-1:2013. ISO, Geneva, Switzerland.

Kechagia, M., D. Basoulis, S. Konstantopoulou, D. Dimitriadi, K. Gyftopoulou, N. Skarmoutsou, and E. M. Fakiri. 2013. Health benefits of probiotics: A review. ISRN Nutr. http://dx.doi. org/10.5402/2013/481651.

Konuspayeva, G., B. Faye, and G. Loiseau. 2009. The composition of camel milk: A meta-analysis of the literature data. J. Food Compos. Anal. 22:95-101. http://dx.doi.org/10.1016/j. jfca.2008.09.008.

Konuspayeva, G., B. Faye, G. Loiseau, M. Narmuratova, A. Ivashchenko, A. Meldebekova, and S. Davletov. 2010. Physiological change in camel milk composition (Camelus dromedarius) 1. Effect of lactation stage. Trop. Anim. Health Prod. 42:495-499. http:// dx.doi.org/10.1007/s11250-009-9449-x.

Laleye, L. C., B. Jobe, and A. A. H. Wasesa. 2008. Comparative study on heat stability and functionality of camel and bovine milk whey proteins. J. Dairy Sci. 91:4527-4534. http://dx.doi.org/10.3168/ jds.2008-1446.

Macedo, L. N., R. H. Luchese, A. F. Guerra, and C. G. Barbosa. 2008. Efeito prebiótico do mel sobre o crescimento e viabilidade de Bifidobacterium spp. e Lactobacillus spp. em leite (Prebiotic ef- fect of honey on growth and viability of Bifidobacterium spp. and Lactobacillus spp. in milk). Ciênc. Tecnol. Aliment. 28:935-942. http://dx.doi.org/10.1590/S0101-20612008000400027.

Molan, P. C. 1992. The antibacterial activity of honey: 1 . The nature of the antibacterial activity. Bee World 73:5-28.

Mundo, M. A., O. I. Padilla-Zakour, and R. W. Worobo. 2004. Growth inhibition of foodborne pathogens and food spoilage organisms by select raw honeys. Int. J. Food Microbiol. 97:1-8. http://dx.doi. org/10.1016/j.ijfoodmicro.2004.03.025.

Northolt, M. D. 1983. Pathogenic microorganisms in fermented dairy products. Neth. Milk Dairy J. 37:247-248.

Riazi, A., and H. Ziar. 2012. Effect of honey and starter culture on growth, acidification, sensory properties and bifidobacteria cell counts in fermented skimmed milk. Afr. J. Microbiol. Res. 6:486498. http://dx.doi.org/10.5897/AJMR10.819.

Sert, D., N. Akin, and E. Dertli. 2011. Effects of sunflower honey on the physicochemical, microbiological and sensory characteristics in set type yoghurt during refrigerated storage. Int. J. Dairy Technol. 64:99-107. http://dx.doi.org/10.1111/j.1471-0307.2010.00635.x.

Shin, H. S. and Z. Ustunol. 2005. Carbohydrate composition of honey from different floral sources and their influence on growth of selected intestinal bacteria: An in vitro comparison. Food Res. Int. 38:721-728. http://dx.doi.org/10.1016/j.foodres.2005.01.007.

Süle, J., and L. Varga. 2009. Méz hatása egy probiotikus savanyú tejtermék mikrobiótájának alakulására (Influence of honey on the viability of microbiota in a probiotic fermented milk). Tejgazd. $69(1): 17-22$.

Ustunol, Z., and H. Gandhi. 2001. Growth and viability of commercial Bifidobacterium spp. in honey-sweetened skim milk. J. Food Prot. 64:1775-1779

Varga, L. 2006. Effect of acacia (Robinia pseudo-acacia L.) honey on the characteristic microflora of yogurt during refrigerated storage. Int. J. Food Microbiol. 108:272-275. http://dx.doi.org/10.1016/j. ijfoodmicro.2005.11.014

Varga, L., J. Süle, and P. Nagy. 2014. Short communication: Survival of the characteristic microbiota in probiotic fermented camel, cow, goat, and sheep milks during refrigerated storage. J. Dairy Sci. 97:2039-2044. http://dx.doi.org/10.3168/jds.2013-7339. 